\title{
Temporal-spatial Patterns of Noctuinae Communities (Lep. Noctuidae) in Hungarian Apple Orchards (Apple Ecosystem Research)
}

\author{
L. HUFNAGEL ${ }^{1,2}$, Z. MÉSZÁROS ${ }^{1}$, MÁRTA GAÁL $^{3}$ and A. FERENCZY ${ }^{3}$ \\ ${ }^{1}$ Department of Entomology of the University of Horticulture \\ and Food Industry, Budapest, Hungary \\ ${ }^{2}$ Department of Systematic Zoology and Ecology of the Eötvös Loránd University, \\ Zootaxonomy Research Group of the Hungarian Academy of Sciences, Budapest, Hungary \\ ${ }^{3}$ Department of Mathematics and Informatics of the University of Horticulture \\ and Food Industry, Budapest, Hungary
}

\begin{abstract}
In our present study we aimed to recognize the temporal and spatial patterns of Noctuinae communities (Lep. Noctuidae) of four differently managed apple orchards laying in different localities of Hungary. Data were obtained by light trap collection.

The quantitative data resulting from our investigations were analyzed by multivariate methods and were also analyzed by their diversity characteristics. As a result connections were found regarding the diversities of species and individuals, the patterns of occurrence and phenological properties. The studies were based on 8497 individuals of 39 species.
\end{abstract}

Key words: Noctuidae, apple orchards, multivariate methods, diversity.

In Hungary the horticultural ecosystem researches have started first, and are still the most extensive in apple orchards.

Starting our present work first of all we carried out an extensive faunistical investigation in the first years (since 1976). The summarized results were published first in 1984 (Mészáros et al., 1984).

During the first five years (1976-1980) in five Hungarian apple orchards (four in east Hungary, in the "Nyírség"; the fifth near Budapest in Nagykovácsi, "Júlianna major") the presence of 1759 animal species was demonstrated with different collection methods. These results are proving the faunistical richness of the apple orchards, and also the relationships between the environment and the examined agricultural areas (Mészáros and Ronkay, 1981). In the course of the later studies our attention has been concentrated on the relationships (Mészáros and Ronkay, 1981).

In the present study the spatial and temporal patterns of the Noctuinae subfamily (Fam. Noctuidae, Lepidoptera) were described in three apple orchards in east Hungary ("Nyírség") and in Nagykovácsi ("Julianna major") based on light trap collections. (In the fourth apple orchard in Nyírség mentioned above no light trap has been operated, so it had to be omitted from present comparative studies). 


\section{Materials and Methods}

The Noctuidae family contains the highest number of species in the Lepidoptera fauna of Central Europe. In Hungary about 500 species are already found. Within this family the Noctuinae (Agrotinae) subfamily is important and homogeneous in many point of view. The larvae are photophobous, mostly living in the soil, others are living at grass level. Many of them are known as dangerous terricol pests. The adults are active at night; being disturbed during the daytime they try to hide as fast as possible. They are usually flying well to light traps. Both the national light trap network and target light traps produce many data about them.

In the present article we have processed the data of 8497 individuals belonging to 39 species, obtained in the periode of 1976-1985.

In the studies the traditional Jermy-type light trap was used, operating with a 100 Watt normal light bulb (Jermy, 1961).

\section{Sites of Assessment}

The experimental orchards are located in the county of Szabolcs-Szatmár and Pest (further on near Budapest).

1. Backyard orchard: Nyíregyháza-Füzesbokor, about 0.5 ha. Receiving regular chemical treatments (11-12 sprayings per year, of which about 8 or 10 are insecticides). Weed cover is $20-40 \%$. Surrounding area: backyard gardens, cropland, scattered little farms.

2. Traditional farming-scale orchard: Újfehértó, about 5 ha. Receiving regular chemical treatment (12-19 sprayings per year, of which about 7-9 are insecticides). Weed cover is $10-50 \%$. Surrounding area: farming scale orchards, cropland, meadows.

3. Intensive farming-scale orchard: Nyíregyháza-Ilonatanya, 100 ha. Receiving regular chemical treatments (11-19 sprayings per year, of which about 7-11 are insecticides). Weed cover is $10-50 \%$. Surrounding area: farming-scale orchards, cropland.

The soil of these three sites is brown sandy soil, the apple variety grown in the orchard is Jonathan (in the farming-scale orchards Starking is used as pollinating variety).

4. Experimental orchard: Nagykovácsi-Júlianna major (near to the city border of Budapest, north from the centre). About the half of the 5.8 ha orchard ( 2.5 ha) is kept as an insecticide-free control area. Weed cover is $40-80 \%$. The surrounding area is mostly forest (Querceto petreae-cerris and Ceraso-Quercetum pubescentis) and cropland plots, surrounded themselves by forest. The soil is brown forest soil.

\section{Methods of Data Analysis}

The data of 39 Noctuinae species found in course of 10 years in 4 areas described above were arranged into tables. In these data tables (as well as in the ordinations discussed later) the species were represented with the respective serial numbers given in Table 1 . The 40 experimental objects were also marked with serial numbers increasing according to the years (from 1976 to 1985) so that the numbers 1-10 represent the first orchard, 11-20 the second, 21-30 the third and 31-40 the fourth apple orchard. The total 


\section{Table 1}

The summarized data by years and areas concerning the Noctuinae species (For a brief format in the field "Data" you can find the number of the orchard, the year of collection and then the number of individuals in paranthesis)

\begin{tabular}{|c|c|}
\hline No. Taxa & Data \\
\hline 1. Euxoa vitta ESPER & 4. $1982(1), 84(1)$. \\
\hline $\begin{array}{l}\text { 2. Euxoa obelisca DENIS et } \\
\text { SCHIFFERMÜLLER }\end{array}$ & $\begin{array}{l}\text { 4. } 1976(1), 77 \text { (2), } 78 \text { (8), } 79 \text { (4), } 80 \text { (4), } 81 \text { (44), } 82 \text { (24), } 83 \text { (32), } 84 \text { (6), } \\
85 \text { (16). }\end{array}$ \\
\hline 3. Euxoa tritici eruta HÜBNER & 2. $1976(3), 77(1), 78(1), 79(2)$ \\
\hline 4. Euxoa nigricans LINNAEUS & 4. $1981(1), 83(4), 85(4)$ \\
\hline 5. Euxoa temera HÜBNER & 4. 1977(3), 78 (3), $79(3), 80(1), 81(67), 82(37), 83(15), 84$ (2), 85 (8). \\
\hline $\begin{array}{l}\text { 6. Euxoa aquilina DENIS et } \\
\text { SCHIFFERMÜLLER }\end{array}$ & $\begin{array}{l}\text { 2. } 1985 \text { (1). } \\
\text { 4. } 1977(1), 79(4), 80(9), 81(30), 82(29), 83 \text { (7), } 85 \text { (27). }\end{array}$ \\
\hline $\begin{array}{l}\text { 7. Agrotis cinerea DENIS et } \\
\text { SCHIFFERMÜLLER }\end{array}$ & $\begin{array}{l}\text { 3. } 1978 \text { (19). } \\
\text { 4. } 1978 \text { (7), } 79 \text { (3), } 80 \text { (1), } 81 \text { (27), } 82(8), 83(19), 84 \text { (2), } 85 \text { (5). }\end{array}$ \\
\hline $\begin{array}{l}\text { 8. Agrotis vestigialis } \\
\text { HUFNAGEL }\end{array}$ & $\begin{array}{l}\text { 2. } 1978(2), 79(5), 80(1) \\
\text { 3. } 1976(4), 77(7), 78(1), 79(1), 80(1), 81(3), 82(3), 83(1)\end{array}$ \\
\hline $\begin{array}{l}\text { 9. Agrotis segetum DENIS et } \\
\text { SCHIFFERMÜLLER }\end{array}$ & $\begin{array}{l}\text { 1. } 1976(34), 77(7), 78(2), 79(2), 80(3), 81(4), 83(2), 84(6), 85(2) . \\
\text { 2. } 1977(5), 78(3), 79(8), 80(9), 85(1) \text {. } \\
\text { 3. } 1976(9), 77(7), 78(6), 79(5), 80(12), 81(6), 82(12), 83(15), 85(3) \text {. } \\
\text { 4. } 1976(11), 77(9), 78(12), 79(10), 80(22), 81(37), 82(94), 83(393) \text {, } \\
\quad 84(11), 85(84) .\end{array}$ \\
\hline 10. Agrotis clavis HUFNAGEL & 4. $1977(1), 79(1), 80(1), 81(10), 82(2), 83(2), 85(2)$ \\
\hline $\begin{array}{l}\text { 11. Agrotis exclamationis } \\
\text { LINNAEUS }\end{array}$ & $\begin{array}{l}\text { 1. } 1976(133), 77(52), 78(17), 79(18), 80(28), 81(29), 82(45), 83(12), \\
\quad 84(8), 85(1) . \\
\text { 2. } 1977(4), 79(2), 80(1) . \\
\text { 3. } 1976(6), 77(1), 78(2), 81(1), 82(2), \\
\text { 4. } 1976(6), 77(17), 78(7), 79(27), 80(18), 81(281), 82(130), 83 \text { (427), } \\
\quad 84(24), 85(168) .\end{array}$ \\
\hline 12. Agrotis ipsilon HUFNAGEL & $\begin{array}{l}\text { 1. } 1976(2), 77(3), 78(3), 80(2), 81(1), 82(1) \\
\text { 3. } 1976(1) \text {. } \\
\text { 4. } 1977(1), 79(1), 81(4), 82(6), 83(21), 85(7)\end{array}$ \\
\hline 13. Agrotis crassa TREITSCHKE & $\begin{array}{l}\text { 1. } 1976(1), 77(2) \\
\text { 4. } 1983(1), 84(3), 85(6)\end{array}$ \\
\hline $\begin{array}{l}\text { 14. Ochropleura praecox } \\
\text { LINNAEUS }\end{array}$ & 2. $1977(1)$ \\
\hline $\begin{array}{l}\text { 15. Ochropleura plecta } \\
\text { LINNAEUS }\end{array}$ & $\begin{array}{l}\text { 1. } 1976(12), 78(36), 79(40), 80(29), 81(21), 82(11), 83(11), 84(2), 85(6) \text {. } \\
\text { 2. } 1985 \text { (2). } \\
\text { 3. } 1976(4), 77(1), 78(1), 79(4), 80(5), 81(2), 82(7), 83(7), 85(1) . \\
\text { 4. } 1978(1), 79(1), 81(10), 82(6), 83(47), 85(22) .\end{array}$ \\
\hline 16. Axylia putris LINNAEUS & $\begin{array}{l}\text { 1. } 1976(11), 77(3), 78(23), 79(24), 80(143), 81(9), 82(15), 83(5), 84(8), \\
\quad 85(27) . \\
\text { 2. } 1977(2), 78(1), 79(1), 80(6) . \\
\text { 3. } 1976(1), 77(3), 78(4), 79(1), 80(2), 81(1), 82(1), 83(2), 85(4) . \\
\text { 4. } 1977(2), 78(4), 79(2), 80(1), 81(25), 82(9), 83(7), 85(32) .\end{array}$ \\
\hline $\begin{array}{l}\text { 17. Eugnorisma depuncta } \\
\text { LINNAEUS }\end{array}$ & 4. $1982(5), 83(1), 85(8)$ \\
\hline $\begin{array}{l}\text { 18. Rhyacia simulans } \\
\text { HUFNAGEL }\end{array}$ & 4. 1984 (1). \\
\hline $\begin{array}{l}\text { 19. Chersotis multangula } \\
\text { HÜBNER }\end{array}$ & 4. 1981 (2), $82(3), 84(2), 85(1)$. \\
\hline
\end{tabular}


Table 1 (cont.)

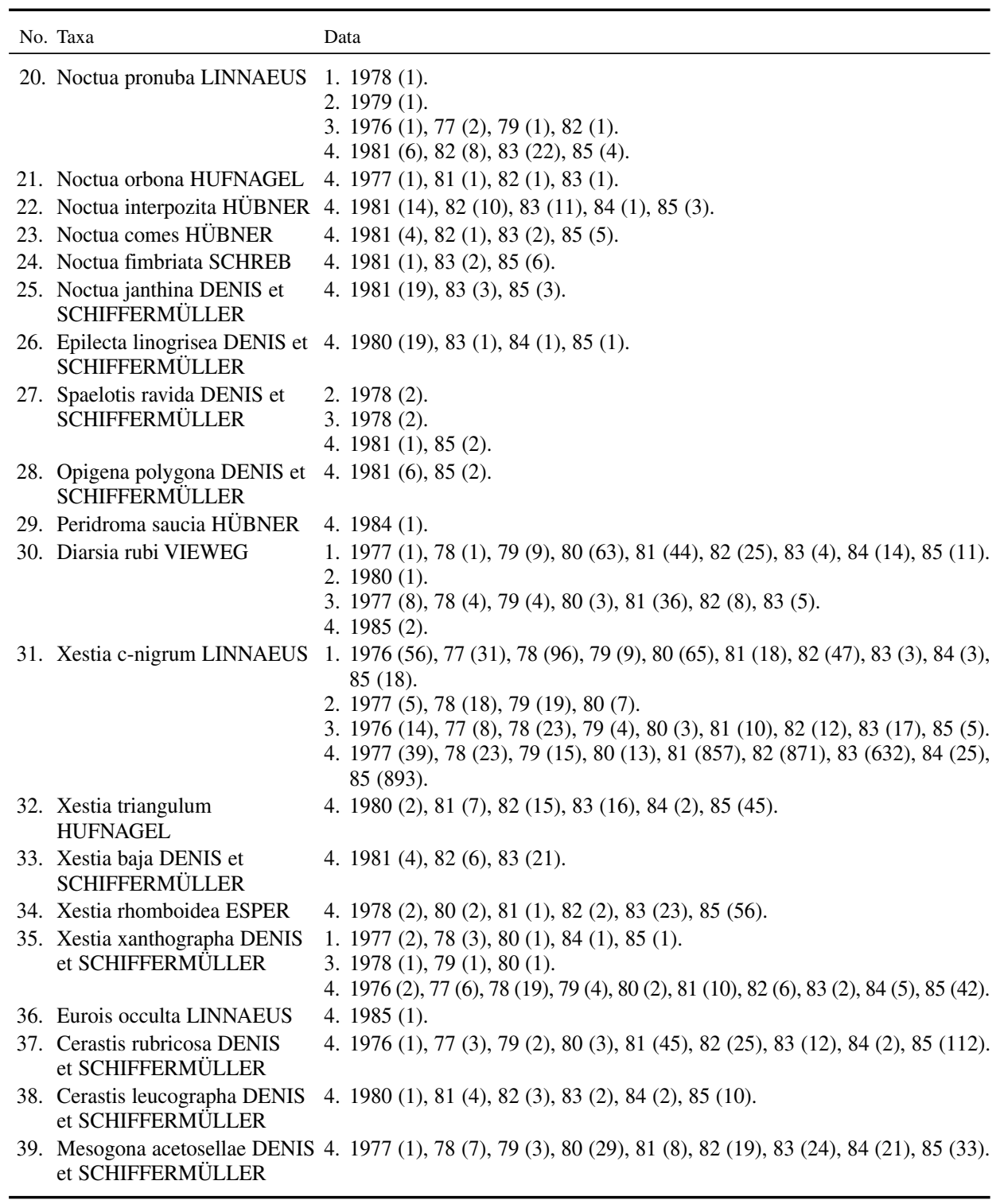


number of individuals by species in the respective years have been entered into the fields of the table. The data matrix was then analyzed by multivariate methods.

The similarity patterns of variables (one year of each area) and objects were separately examined. The analyses have been carried out both with presence-absence data and quantitative ones. To obtain several information hidden in the data structure many types of analysis were carried out (metrical and non-metrical ordinations, hierarchical classifications both with distance- and homogeneity optimization). From these analyses only a few can be presented in this article, but they were all considered in drawing our conclusions. The relationships between the similarity patterns of objects and variables were explored by re-arranging the data tables obtained by superimposing the objects and the hierarchical classifications (dendrograms). The advantage of the re-arranged tables is that they contain the basic data, so eventual methodological faults or artifacts can be easily recognized. The ordination figures presented in this article have been constructed by Metrical Multidimensional Scaling (Principal Coordinates Analysis, PCoA) by using Euclidean distances at the quantitative data, and PHI- at the absence-presence data. The PCoA is based on the symmetric distance matrix of the objects, then by using eigenvalues and eigenvectors obtains the coordinates mentioned in its name.

The PCoA is a dimension-reducing method, which keeps the original ratio of the distances. Because of its simplicity and expressivity, the Euclidean distance is the most universal distance function for binary data, as well as for quantitative data. The PHI metrica can be applied only in binary cases, its advantage is that the differences in the frequency relations of the variables (which are sometimes significant) do not mask the principal pattern, so we can obtain information similar to the association. We used the SYNTAX program package for all multivariate analyses (Podani, 1993a, b, 1994, 1997).

Analyzing the diversities, we tested many kinds of traditional indices, but in many cases they have led to basically different results, which refer to the differently appearing uniformity in the number of species and in the frequency relations of the species. In the purpose of clearing up the question using both the dominance (frequency by the total number of individuals), and the constancy (relative frequency of presence reference to 10 years) data, we applied diversity-orderings (scale dependent diversity characterizations) by the NuCoSa program package. The diversity-orderings represented in this study, were calculated the Rényi's diversity. The Rényi's diversity is a generalization of the well-known and the most widely applied Shannon entropy, which consists an optionally changeable scale parameter. By the help of this we can make a diversityordering, which makes possible a more precise interpretation than the simple indices. When the value of the scale parameter is 1 the Rényi's diversity gives the Shannon function, while at the value of 0 , it gives the logarithm of the number of species. The 0 value of the function shows the diversity from the point of view of the rare species (number of species), the higher values shows the diversity from that of the dominant species (uniformity) (Tóthmérész, 1995, 1996, 1997). 


\section{Results and Discussion}

The data of the species found

In the course of the investigation 8497 Noctuinae individuals came to light, which belonged to 39 species. Among these 39, we could not find some species which are generally abundant in the samples of light traps, so we consider that the apple orchard around the light trap determines or has a great influence on the composition of species.

The summarized data (by years and areas) concerning the Noctuinae species obtained from the light trapping in apple orchards, can be found in Table 1. It can be considered as the primary results of the research, all the analyses found in the present article can be derived from these data. We can get a comprehensive view and basis of comparison about the whole material focusing on its composition according to the dominance (Table 2) and the constancy (Table 3).

Table 2

The composition of the collected regarding the number of individuals

\begin{tabular}{lcc}
\hline Taxa & No. of individuals & Dominance $(\%)$ \\
\hline Xestia c-nigrum & 3859 & 45.42 \\
Agrotis exclamationis & 1467 & 17.27 \\
Agrotis segetum & 846 & 9.95 \\
Axylia putris & 379 & 4.46 \\
Ochropleura plecta & 289 & 3.40 \\
Diarsia rubi & 243 & 2.86 \\
Cerastis rubricosa & 205 & 2.41 \\
All the 32 remained species & 1209 & 14.23 \\
\hline
\end{tabular}

Table 3

The most frequent species in the 40 sampling units

\begin{tabular}{lcc}
\hline Taxa & Presence & Constancy $(\%)$ \\
\hline Agrotis segetum & 33 & 82.5 \\
Xestia c-nigrum & 32 & 80.0 \\
Axylia putris & 31 & 77.5 \\
Agrotis exclamationis & 28 & 70.0 \\
Ochropleura plecta & 25 & 62.5 \\
Diarsia rubi & 18 & 45.0 \\
Xestia xanthographa & 18 & 45.0 \\
\hline
\end{tabular}

Comparision of the Noctuinae assemblages found in the sampling units

The four examined orchards are very different also based on the summarized data of the ten years of Noctuinae species (Table 4).

According to the expectations, considering both the number of individuals as well as the number of species, the insecticide-free area is a specific one. However it is 
Table 4

Summarized data by orchards

\begin{tabular}{ccccc}
\hline Orchard & $\begin{array}{c}\text { Sum of } \\
\text { individuals }\end{array}$ & $\begin{array}{c}\text { No. of } \\
\text { species }\end{array}$ & $\begin{array}{c}\text { No. of } \\
\text { species/individuals }\end{array}$ & $\begin{array}{c}\text { Dominance of } \\
\text { dominant species (\%) }\end{array}$ \\
\hline 1 & 1383 & 10 & 0.0072 & 25 \\
2 & 115 & 12 & 0.1043 & 42 \\
3 & 335 & 12 & 0.0358 & 28 \\
4 & 6664 & 36 & 0.0054 & 50 \\
\hline
\end{tabular}

surprising that in this area ("Júlianna major") is the least number of species per number of individuals, which has a relationship with the high dominance of the dominant species (Xestia c-nigrum), too. From the point of view of the dominance of the dominant species, the backyard garden appears to be the most diverse, which has the least of species. Further difficulty appear in the interpretation of diversity relations that the number of species per number of individuals reaches the most prominent value in none of this two, but in the traditional orchard of Újfehértó. All these results call our attention to the fact that in agricultural areas in case of biodiversity assessment and in the selection of technologies (agrotechnics, plant protection) preferred in natural conservation aspects, it is necessary to be more careful than it was used to do earlier.

In order to explore the similarity pattern of the 40 objects examined (total yearly data of 4 areas during ten years), ordinations were carried out, using presence-absence and quantitative data. In case of the ordination obtained from the presence-absence data it can be seen that the 40 objects are separated as they belong to four areas (Fig. 1). It

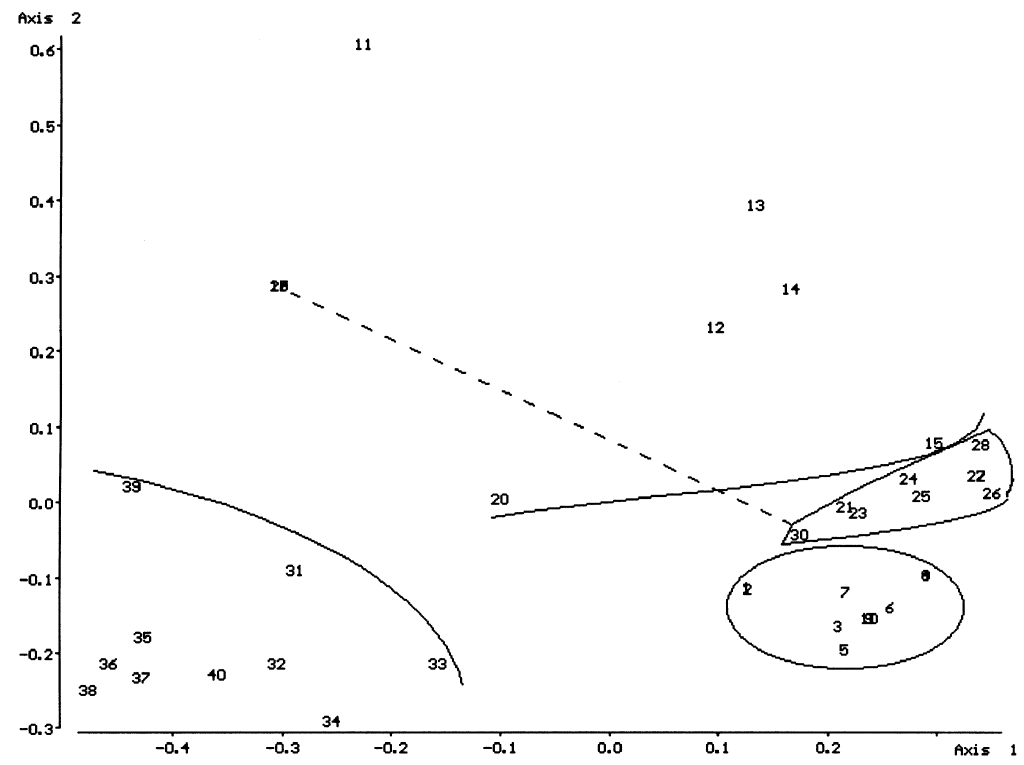

Fig. 1. Similarity pattern of the 40 objects examined based on the presence-absence data of the species (NMDS, PHI-metric) 
means that the changes during the years do not cover the differences revealed in localities. So, the character of the habitat influence the catch results of the light trap stronger than the parameters changing during the years (weather, environmental changes, etc.). If we examined the ordination obtained from the quantitative data we would not get this result, because the data of 4 prominent years $(1981,1982,1983,1984)$ of the sampling area 4 would get so far from all the others that the distances among them would not clearly visible. In order to mask this phenomenon, logarithmic transformation was applied in the database. In the figure prepared in this way (Fig. 2), the objects are visible separately yet. It can be stated that in this case the areas 4 and 1 are the most separated. The objects of the areas 2 and 3 are close to each other, but we can recognize the two groups.

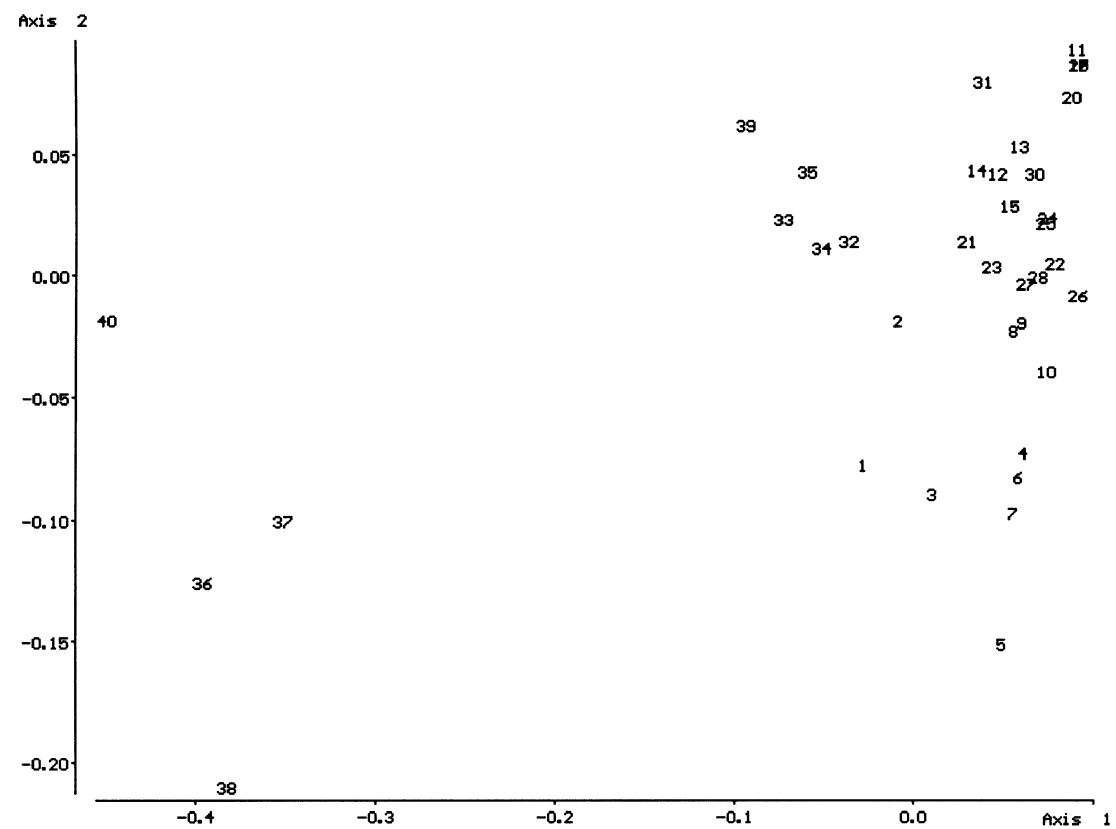

Fig. 2. Similarity pattern of the 40 objects examined based on quantitative data of the species (NMDS, Euclidean distance, logarithmic transformation)

In order to understand more precisely the phenomenon described above, three further ordinations were made, for the ten years total quantitative data of the 4 areas. One for the sum of the individual numbers (abundance), one for the dominance (standardization concerning the objects), and one for the constancy during the ten years (Fig. 3). It can be seen on all three of the figures that the areas 1 and 4 are always the furthest to each other. Regarding the sums the areas 2 and 3 are close to each other, but equally far from the areas 1 and 4 . In case of the dominance areas 2 and 3 are further to each other, area 2 moves towards area 4 . At the constancy the image is similar, although area 3 comes closer to areas 1; 2 is far from both areas 1 and 4, and 3 is the one which stands relatively close to it. 
Axis 2

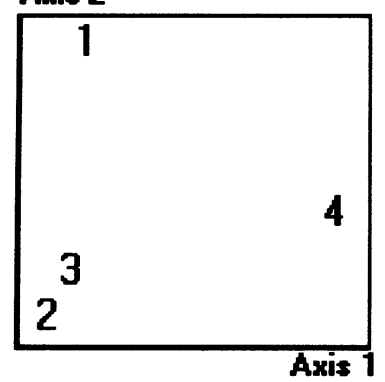

Abundance
Axis 2

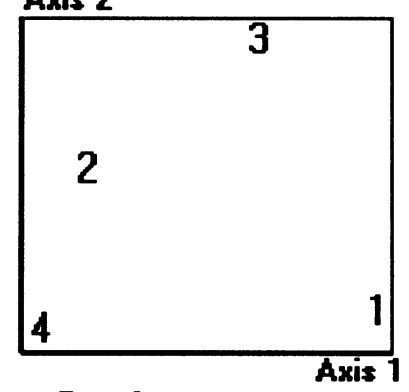

Dominance

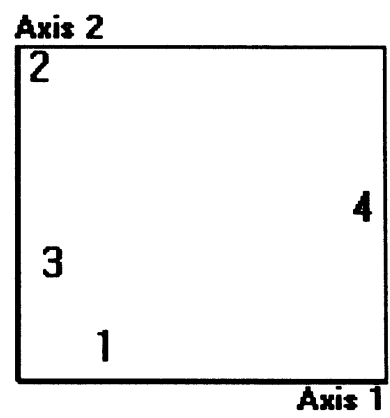

Constancy

Fig. 3. Similarity pattern of the four orchards based on the summarized data of ten years (1976-1985)

Summarized: The areas 1, 2, 4 are always far from each other, area 3 is always between areas 1 and 2 (occasionally closer to either of them), but the furthest from area 4. All these are partly clear considering in Table 4, in the point of view of the species number and the number of individuals the areas 2 and 3 are the closest to each other, area 1 is further, area 4 is even more further, while in case of the dominance of the dominant species the area 1 and area 3 are standing close to each other. These similarity patterns point out many relationships although in the relation of the dominance they cannot provide a clear answer.

\section{The species-individual diversity of the Noctuinae communities in apple orchards}

Comparing the similarity patterns of the different areas, and considering the diversity anomalies underlined in Table 4 it seems necessary to apply a diversity ordering for the 4 areas. With this object, Rényi's function was used for diversity-orderings. Two analyses have been carried out, one on the basis of the individual numbers of the species (=dominance), another on the basis of the constancy data of the species.

In case of the individual numbers (Fig. 4A) all of the four curves intersect each other, so the areas cannot be ordered in diversity aspect. On the basis of the rare species the descending order of the diversities is: areas $4,3,2,1$, on the basis of the frequent species of the areas $1,3,2,4$. So the orders are more or less opposite, that is to say the higher species number is accompanied by lower uniformity.

Considering the diversity ordering in case of the constancy (Fig. 4B) the situation is more simple. The area 4 is prominently the most diverse compared to the all three of the remained; area 3 is more diverse than 1, the curve of area 2 intersects the curves of areas 3 and 1, too, so this area cannot be ordered in the relation of this two. In case of the rare (a little constant) species area 2 is slightly more diverse than area 3 , at the scale parameter of 1.0-3.0 (around the Shannon-diversity) area 3, 2, 1, is the descending order of the diversity, and in case of the frequent (highly constant) species the order is area 3 , 1, 2. So in case of constancy the type of the distribution is different than in case of the dominance. Where more species are, also the ratio of constancy is more uniform. 


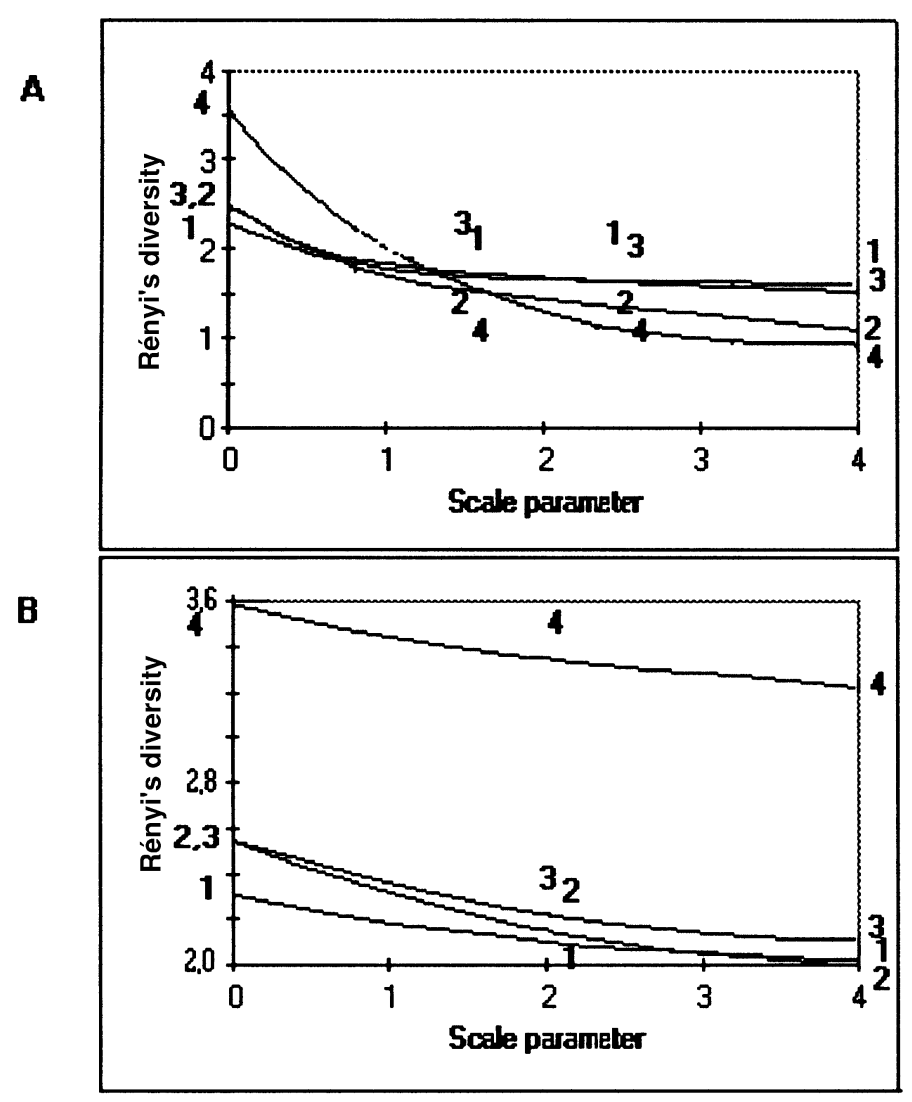

Fig. 4. Comparison of the species-individual diversity of the four orchards based on dominance (A) and constancy (B) using the Rényi's diversity

To get more precise explanation of the problem we made a diagram (Fig. 5A) which shows the relationships between the number of species and the number of individuals for the 40 objects examined. It can be seen in Fig. 5A that as the number of individuals ascending, the number of species also, however it is suspicious that there are two, a lower and a higher saturating curves superimposing. Indeed separately describing the insecticide-free area 4 (Fig. 5B) which consists of higher individual numbers and the areas 1, 2, 3 (Fig. 5C), having approximately similar range of their data, we can obtain two curves seems to be saturating ones. The "saturated" species number of the area 4 is between 25 and 30, and that of the managed areas 1, 2, 3, are about 8. (There are differences in the lowest values as well: in the first case it is 5, in the second it is 0 and 1.) In the first case the "saturated" number of species is about 400-1200 individuals, in the second it stabilize at about 50 individuals.

After all this we have to examine the relationship between this results and the presence pattern of the species. 


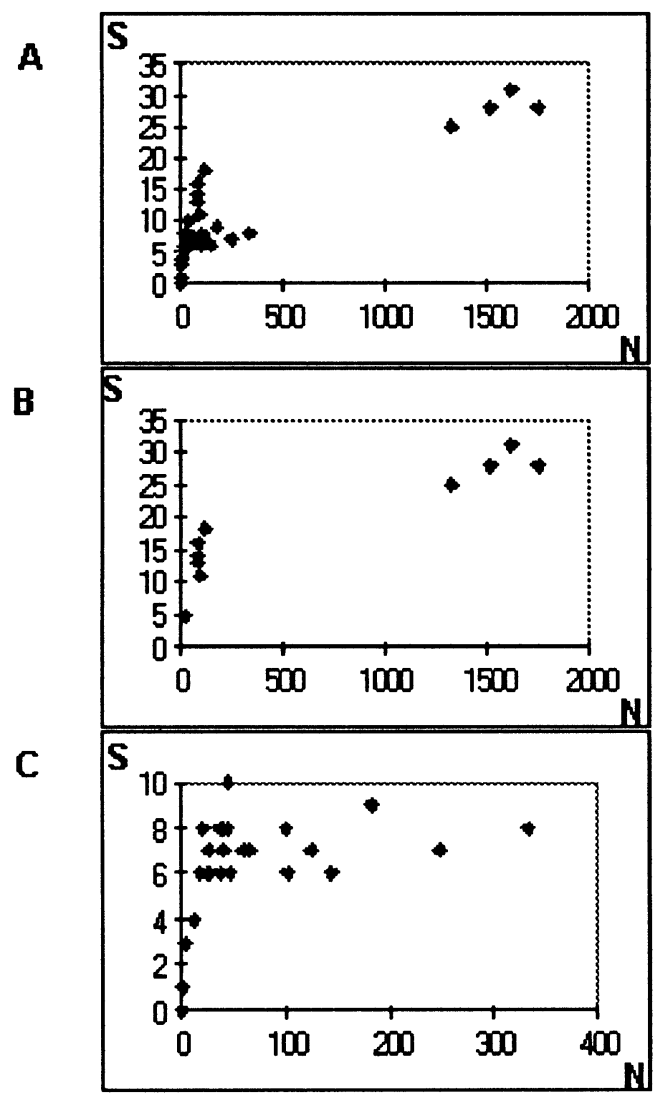

Fig. 5. Relationship between the number of species and individuals.

A - all of data, B - data of "Júlianna major", C - data of the three orchards in Nyírség

The presence pattern of the species

Analyzing the similarity patterns of the species on the objects ordinations were made, too. According to the quantitative data (Fig. 6) most of the species are in one group (rare species), while there are 3-3 species separated.

Xestia c-nigrum, Agrostis exclamationis, A. segetum, and Axylia putris, $O$. plecta, Diarsia rubi. The analysis of the presence-absence data using phi metric (Fig. 7) is favorable to the patterns of the rare species. Here the species separate in three groups:

1. The six species listed above plus $A$. vestigalis, $O$. praecox, E. tritici.

2. Euxoa vitta, Phyacia simulans, P. saucia.

3. All the remained (27 species).

With the aim of controlling the ordination methods and exploring the relationships between the species groups and object groups (areas), cluster analyses were carried out for the species and for the objects as well. Then projecting the results of the two cluster analyses we obtained the transformed version of the original data table. 


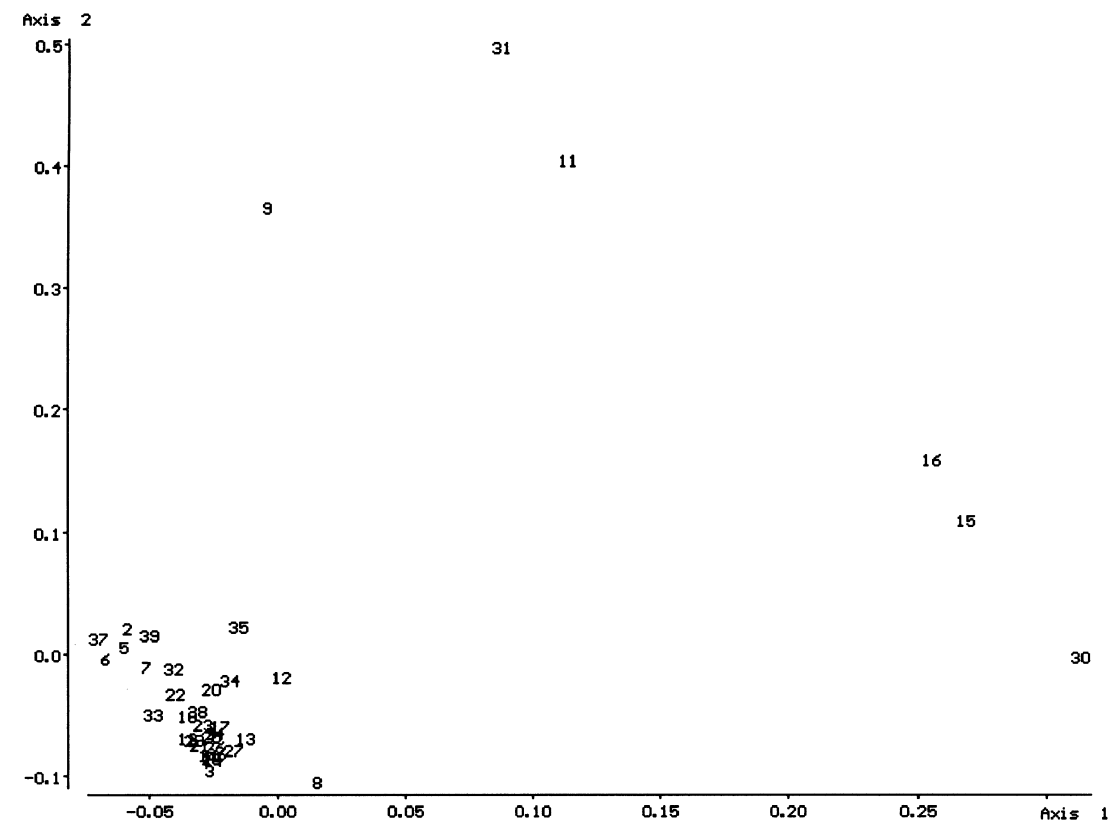

Fig. 6. Similarity pattern of the 39 Noctuinae species based on quantitative data (NMDS, Euclidean distance, logarithmic transformation)

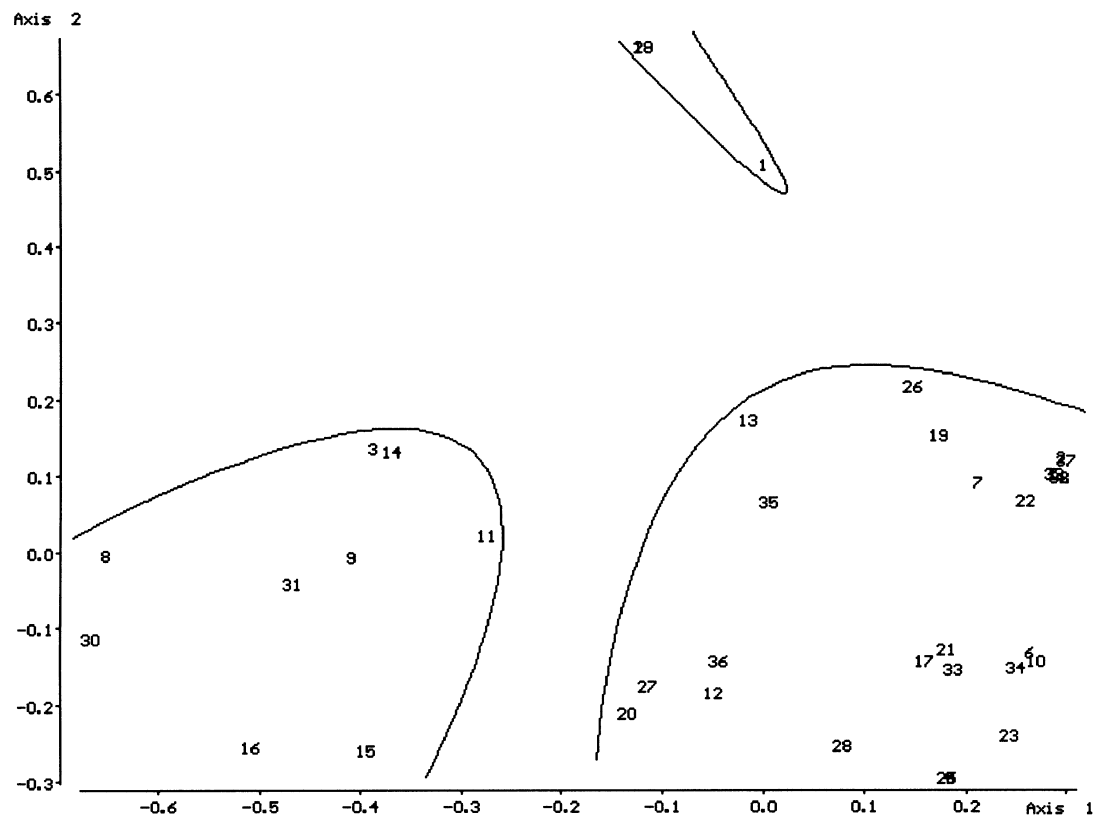

Fig. 7. Similarity pattern of the 39 Noctuinae species based on presence-absence data (NMDS, PHI-metric) 
By means of the transformed table we have the opportunity to cluster the species on the base of their presence patterns:

1.a. Basically common species: Xestia c-nigrum, Agrostis exclamationis, A. segetum, Axylia putris, O. plecta, N. pronuba, A. ipsilon, X. xanthographa.

1.b. Avoids the very diverse area 4 (although basically common): Diarsia rubi.

2. Occur basically only in the area 4: Most of the species.

Note: Occur only in the area 2: E. tritici, O. praecox. Typical of the area 3 (and to a less degree of area 2): A. vestigalis.

Interesting relationships can be obtained comparing the presence groups mentioned above to the phenological types of the species:

All the bivoltins belong to the group 1, they are basically common. The common are dominated by the bivoltin species. There are real and inner migrant species among them.

The group 2 is dominated by the univoltins. Most of the species belong to the group 2. They are characteristic to the area 4.

There are no strictly common species among the migrating moths. The migrating moth species are not dominant anywhere.

By means of taxonomy: The Euxoa spp., and Noctua spp. are characteristic to the unmanaged area 4 .

\section{Literature}

Jermy, T. (1961): Kártevő rovarok rajzásának vizsgálata fénycsapdákkal. [Study of the swarming of pests with light traps] A Növényvédelem Időszerü Kérdései, 2, 53-60.

Mészáros, Z. and Ronkay, L. (1981): A comparative study on the Macrolepidoptera fauna of apple orchards in Hungary (Res. of Apple Ecosystems, No. 18.). Acta Phytopath. Acad. Sci. Hung. 16, 409-421.

Mészáros, Z. (ed.) (1984): Results of Faunistical and Floristical Studies in Hungarian Apple Orchards (Apple Ecosystem Research No. 26.). Acta Pythopath. Acad. Sci. Hung. 19, 91-176.

Podani, J. (1993/a): SYN-TAX Version 5.0 User's Guide. Scientia, Budapest, pp. 104.

Podani, J. (1993/b): SYN-TAX. Computer programs for multivariate data analysis in ecology and systematics. Abstracta Botanica 17, 289-302.

Podani, J. (1994): Multivariate Data Analysis in Ecology and Systematics. SPB Publishing, The Hague.

Podani, J. (1997): Bevezetés a többváltozós biológiai adatfeltárás rejtelmeibe. [Introduction to the multivariate biological data analysis] Scientia Kiadó, Budapest, 5-412.

Tóthmérész, B. (1995): Comparison of different methods for diversity ordering. Journal of Vegetation Science 6, 283-290.

Tóthmérész, B. (1996): NuCoSA: Programcsomag botanikai, zoológiai és ökológiai vizsgálatokhoz. [NuCoSA: Program package for botanical, zoological and ecological analysis] Scientia Kiadó, Budapest, 5-83.

Tóthmérész, B. (1997): Diverzitási rendezések. [Diversity orderings] Scientia Kiadó, Budapest, 5-98. 